Gian Antonio GILLI, L'età delle membra. Antropologia delle parti del corpo [The Age of the Parts: The Anthropology of Body-parts]

\title{
Roberto Alciati
}

\section{(2) OpenEdition \\ 1 Journals}

Electronic version

URL: https://journals.openedition.org/ress/4817

DOI: $10.4000 /$ ress. 4817

ISBN: 1663-4446

ISSN: $1663-4446$

Publisher

Librairie Droz

\section{Printed version}

Date of publication: 30 May 2019

Number of pages: 292-295

ISSN: 0048-8046

\section{Electronic reference}

Roberto Alciati, "Gian Antonio GILLI, L'età delle membra. Antropologia delle parti del corpo [The Age of the Parts: The Anthropology of Body-parts]", Revue européenne des sciences sociales [Online], 57-1 | 2019, Online since 21 March 2019, connection on 03 January 2023. URL: http://journals.openedition.org/ ress/4817 ; DOI: https://doi.org/10.4000/ress.4817

This text was automatically generated on 3 January 2023.

All rights reserved 


\title{
Gian Antonio GILLI, L'età delle membra. Antropologia delle parti del corpo [The Age of the Parts: The Anthropology of Body-parts]
}

\author{
Roberto Alciati
}

\section{REFERENCES}

Gian Antonio GILLI, 2016, L'età delle membra. Antropologia delle parti del corpo [The Age of

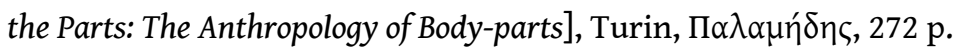

1 Considered as a theoretical issue, the body has become quite popular among anthropologists, sociologists-and later historians-in the last forty years. It was Mary Douglas who first spoke explicitly of an "anthropology of the body", conceived as a new perspective for investigating the processes of its cultural construction, by way of a comparative approach. Gian Antonio Gilli, however, affirms that there is still a lot to say about the body, if we are willing to change radically our point of view.

2 There is no doubt that the body is perceived and experienced through cultural, political, religious and social filters. But what happens if we redefine or forgo the body as an indistinct unit, thereby conceiving it as construction-structured and structuring, as Pierre Bourdieu would have said-that is given only because its constitutive parts precede it? The programmatic statement formulated by the author is quite clear on this point: "it is true that in the historical and sociological literature of the last decades there are countless contributions (perhaps thousands) that already have in the title a reference to the body. However, on the basis of a different perspective-the one we are following here-they have all exhibited a common limit, since they all ignore the several parts that constitute a body, totally inspired as they are by the postulate that the body is itself, from the outset, a unitary entity" (p.76). 
3 This is the provocative question that provides the backdrop for this book-and for most of the work undertaken by its author in the last twenty years at least-, which is divided in two parts, respectively entitled "Il modello" [The model] and "Testimonianze e frammenti" [Testimonies and fragments]. The first part (chaps. 1-3) describes the theoretical framework, whilst the second part contains an anthology of quotations and testimonies (280 entries) organized in nine paragraphs. All this is preceded by an introductory chapter, within which the author draws the attention of his readers to his main concerns and overarching arguments.

4 Assuming the pre-existence of the parts with respect to the undivided unity we call the "body" and considering the former as what is to be found "at the beginning" amounts to questioning two concepts: gradualism and the supposed societal complexity, which are both usually considered the basic forms of complexity, as historically documented. All this is closely related to a key problem in historical-sociological research, that of origins. Gilli writes: "Let us look, for example, at the most famous origin, that is the origin of society. Society, it is said, gradually affirmed itself, gradually the arts and sciences were born and developed, and so on" (p.9). To understand how smoothly the mechanism runs, just look at Xenophanes of Colophon $\left(6^{\text {th }}-5^{\text {th }} c\right.$. BCE) and contemporary biologists. Both, faced with the emergence of something new, turned to gradualism and the transition from the simple to the complex. On the contrary, the aim of this book is to show that the emergence of the body is a break of such a magnitude that it renders it incompatible with any gradualism. In this respect, the body allows for the replacement of one kind of complexity by another. And replacement usually takes place suddenly, not gradually.

5 This theoretical assumption determines the orientations adopted by the method of investigation, therefore justifying, so to speak, the "supremacy" of sociology over history. This is a crucial point in Gilli's perspective: "a research on origins also needs a methodology, but this must be perceived in a different way when compared with other types of research, most notably with regard to historical research, to which this specific investigation would be spontaneously traced back". This diversity, Gilli points out, "derives from the fact that the problem of the Origins - of any Origin - is a sociological problem, rather than a historical one" (p.11). The implication of this assumption is clear enough: a sociological perspective cannot only reconstruct the past. On the contrary, it looks at the present day and is given in view of an intervention. This intervention is essentially aimed at becoming aware of that original condition, lost and/or suppressed, in view of a negotiation. We know well how long, rich and complex the development of the relationship between history and sociology is: starting, at least, from Max Weber onwards, this relationship was always perceived as a fundamental problem. On the one hand, sociologists have often felt compelled to explain specific configurations of change in well-defined historical settings; on the other hand, (many) historians have never shied away from the effort of constructing synchronic structural representations of whole social systems. Gilli's point of departure is completely different, since a technical division of labour between sociologists and historians (but also biologists, psychologists, etc.), and therefore the sum of the competences coming from these different research fields and methods is not a desirable condition. The "problem of the Origins" needs imagination to be solved.

6 This is certainly the most puzzling methodological proposal and one that deserves further attention. The problem of origins exists only as a requirement of the present 
time, and it only takes shape when the discomfort of organized life within any society leads an individual to believe that something different is possible-and therefore possible to imagine-at the beginning of everything (p.14). In this statement, one can hear the echo of Michel Foucault talking about the episteme, that is the structures underlying discourses belonging to determined historical periods. In his Archéologie du savoir (Paris, Gallimard, 1969, p.250-251), Foucault claims that the identification of the episteme makes it possible to grasp the set of constraints and limitations, which, at a given moment, are imposed on discourse. If we replaced the term "discourse" with "body", the meaning of the sentence would remain the same, allowing also a better understanding. The author is aware of the fact that imagination has no place among the tools of scientific research, but he nonetheless considers it an essential instrument that a human being can use to dismantle or criticize regularity, which is always considered a "natural" factor.

7 In the first chapter of the book, two points are addressed in more detail: the preexistence of multiplicity with respect to the body and the criticism of functionalism. From the Greek archaic age to Friedrich Nietzsche, traces of the "age of the parts" seem to be quite present. This is what Gilli calls "an archaic local memory". The body has its own memory, but also each and every part of the body itself has it. And as consequence, the thought is produced and stored by each of the five senses, as witnessed by late antique Manichean literature, or Peruvian Cashinahua populations as well (p.36). The consequence of this kind of thinking is the rejection of finalism and of the assumption according to which parts are primarily acting for the functioning of the system. If even the eye or the act of touching has its own memory, then the idea that their functioning is determined by serving only the memory of the body system makes no sense. The parts are - and must be considered, at least theoretically - self-sufficient (p.48-49).

8 The relationship between the parts and the whole is also central to the second chapter, within which the analysis of Plato's Timaeus is particularly interesting. According to Gilli, Timaeus is the Platonic dialogue that, among all the other ancient sources, best explains the division of labour, i.e. its advantages for the centre and the real costs borne by the parts (p.92). The lesson to be learned is that is impossible to get out of this dialectic at both the societal and physical levels. Bodies, be they social or physical, are always bodies and the pre-existence of the parts that make them up cannot be hidden or silenced forever. Thus the negotiation begins, and it is described in a synthetic and effective way at the end of the chapter: "complexity can only be imposed by a part that, in this way, becomes hegemonic [...]. In other words, every organized complexity is a complexity that has arisen, and every complexity that has arisen has 'violent' origins; violence is all the greater as a more radical level of complexity is achieved" (p.102-103).

9 From the third chapter onwards - the last of the first part - the tone of the narrative changes considerably, as the number of quotations and literary references increases progressively, especially those borrowed from Antiquity. From Homer to Empedocles, the body seems to be thought of, first of all, as a series of related parts. But in these narratives it seems that these parts have their own destiny, which is not the same destiny of the components of an organism.

10 At this point, the second part of the book begins: a rich anthology of testimonies, drawn from various and distinct cultural traditions and chronological periods. As introduced by the author, "this section recalls some of the fundamental themes of the age of the parts. First of all, the characteristics of the origins: individual diversity; 
complexity as a starting point; the epistemological need to 'build' the body. And then, in addition: the primacy of composition [...]; the work done by the Parts for themselves; self-sufficiency. At the end, it follows a series of testimonies on individual parts: breathing, skin, soul" (p.132). Unlike the previous chapters, where the parts are at the core of the analysis, here Gilli focuses on the struggle between the parts and the body or on what is called the adaptation of the parts to the body. This process is described through a decalogue that would indicates the characteristics-but not the stages in a chronological sense-of this adaptation (p.167).

11 The author of this book is to be congratulated for bringing together this volume that includes far more than I have been able to discuss here. The above-mentioned chapters positively contribute to a number of important, intersecting discussions within the field of sociology and history, but also within the field of religious studies. I would like to point out at least two of them.

One such conversation concerns the issue of conflict. There is no need to endorse the Marxist assertion that class conflicts are central to all societies, in order to understand how much conflict is an "evergreen" theme in current historical and sociological research. In this book, Gilli shows to what extent conflict-and therefore the necessary negotiation to neutralize it-is ingrained in self-perception itself.

The second issue is related to the understanding and use of the "body" as a analytic category for the study of religion, with respect to the idea of self-sufficiency. In one of his previous books, Gilli argued that Christian stylites cannot be considered selfdestructive persons or advocates of extreme self-punishment (Arti del corpo. Sei casi di stilitismo [The Arts of the Body: Six Cases of Stylitism], Cavallermaggiore, Gribaudo, 1999). In a Nietzschean perspective, we should consider self-deprivation as an indication not of poverty, but rather of the self-sufficiency of life, as the ascetic takes himself out of the line of the "condemning sin", placing himself beyond good and bad, disintegrating the moral, self-styled Christian from the world. In this last book, this idea is reaffirmed, to the point that it can become a useful hermeneutic tool for a comparative history of asceticism.

14 Although it is undoubtedly a rich and engaging volume, one last warning is necessary: it is not an easy read. But, in the end and at the end, the "intrepid" will certainly delight in the new framework of the body that the author uncovers.

\section{AUTHORS}

\section{ROBERTO ALCIATI}

University of Florence - Department of History, Archaeology, Geography and Arts 